\section{Andrej Stopar \\ University of Ljubljana}

Slovenia
2015, Vol. 12 (1), 105-118(144)

revije.ff.uni-lj.si/elope

doi: 10.4312/elope.12.1.105-118

UDC: [811.111'243:37.091.3]:316.647.8(73)

\title{
Encounters with National Stereotypes in Foreign Language Teaching: Adjectives Describing Americans
}

\author{
ABSTRACT
}

Teaching (or learning) a foreign language is a complex, interdisciplinary undertaking. Teachers and students are required to tackle aspects of language that transcend its merely linguistic component. This article discusses the relationship between language, thought and culture, and explores some aspects of the integration of cultural content in the English classroom. To achieve these goals, a study is conducted that identifies the main stereotypes about Americans among Slovenian university students of English as a foreign language. The results of the research can be used as a means of questioning some frequent stereotypes about Americans, and thus contributing to the fulfilment of (sometimes seemingly abstract) curricular aims that emphasize the significance of intercultural communication, awareness of cultural variety, and intercultural sensitivity.

Keywords: national stereotypes; teaching culture; curriculum; intercultural communication

\section{Srečevanja z nacionalnimi stereotipi v tujejezikovnem poučevanju: Pridevniki, ki opisujejo Američane}

\author{
POVZETEK
}

Poučevanje (ali učenje) tujega jezika je zapleteno in interdisciplinarno delo. Učitelji in učenci se spopadajo z vidiki jezika, ki presegajo zgolj njegovo jezikovno komponento. Članek zato razpravlja o odnosu med jezikom, mislijo in kulturo ter se osredinja na nekatere vidike vključevanja kulturnih vsebin v poučevanje angleščine. To doseže s proučevanjem stereotipov: prispevek predstavi ugotovitve ankete, ki razkriva glavne stereotipe o Američanih med slovenskimi študenti angleščine. Rezultati raziskave lahko pripomorejo k dekonstrukciji pogostih stereotipov o Američanih in tako prispevajo k uresničevanju (včasih navidezno abstraktnih) ciljev v učnih načrtih, ki poudarjajo pomembnost medkulturne komunikacije, zavedanje kulturne raznolikosti in medkulturno občutljivost.

Ključne besede: nacionalni stereotipi; poučevanje kulture; učni načrt; medkulturna komunikacija 


\section{Encounters with National Stereotypes in Foreign Language Teaching: Adjectives Describing Americans}

\section{Introduction}

Language teachers, especially those teaching cultural classes to foreign language (henceforth, FL) learners, often encounter preconceptions about the culture(s) their class is centred on. It is thus desirable and useful for them to explore the ideas, opinions, and even prejudices that their students may possess about the culture(s) and society (or societies) studied. When considering commonly held beliefs about the speakers of the target language, FL teachers should also reflect on: the complexities of the relationship between language, thought, and culture; the ways in which they approach cultural content; and the impact their work consequently has on their students' interaction with target-language speakers and intercultural communication in general.

The main aim of the article is to identify stereotypes about Americans that are prevalent in Slovenian students of English as a FL. To achieve this goal, a study is conducted that focuses on the beliefs of Slovenian university students of English. The reported stereotypes about Americans are also compared with the results of studies that explore the image(s) Americans have about themselves. Additionally, the study aims to identify which connotations are typically ascribed by Slovenian students to the adjectives denoting (stereo)typical American traits. In the process, the paper also addresses the relationship between language and culture, its implications for the language classroom, as well as the nature of stereotypes and some possible ways of handling them in the classroom.

The article is structured as follows. Section 2 presents an overview of literature related to language, thought and culture; teaching cultural content; national stereotypes; and tackling stereotypes in the classroom. Section 3 details the study on stereotypes about Americans in Slovenia. The last section (4) is a discussion of results and their implications for FL teaching.

\section{Literature Overview}

\subsection{Language, Thought, and Culture}

The "network of language, culture and behaviour" (Whorf 1956, 156) has long been part of scientific inquiry. In the first half of the twentieth century, Benjamin Lee Whorf and Edward Sapir proposed that our culture determines our language, and that language affects our thoughts. Their influential ideas meant that the very structure of language also determines, or at least influences, the manner in which we conceptualize reality. Although the principle of linguistic determinism (or its weaker version, linguistic relativity) has been largely refuted and often substituted for theories of, for instance, universal grammar, some of Sapir's and Whorf's claims are evident in a number of more recent studies that explore the link between language and thought. In one such study, Konishi (1993) suggests that grammatical genders shape the feelings of speakers towards objects around them: the masculine form of el puente (bridge) in Spanish is thus perceived as "higher in potency" (Konishi 1993, 519) when compared to the feminine die Brücke in German (also see Deutscher 2011 for other examples).

A question may arise about the impact of the above claims on FL teaching and learning. In an extreme scenario, stating that the speakers of language $x$ perceive the world in a different way from 
the speakers of language $y$ would suggest that teaching/learning an FL should, at least to some extent, be equated with teaching/learning the ways of thinking typical for the target culture. An example of linguistic research that conforms to these principles and has simultaneously significantly affected teaching practices is research on sexist gender-biased language. The approaches to using non-sexist, gender-neutral usage of language vary from one culture to the other (see Plemenitaš 2014, 25-28, for a comparison between English and Slovenian), but the basic tenet remains: changing the linguistic practices should change people's conceptualization of reality, and consequently their culture.

Even though deterministic explanations of the relationship between language and thought may not be equally relevant to every linguist, there appears to be a general consensus (see Byram, Gribkova, and Starkey 2002; Kramsch 1995b, 1993 among others) that in FL teaching and learning, cultural content is unavoidable, indeed essential. In fact, Brown $(2000,177-78)$ presents language as a fundamental expression of culture by (famously) stating that "a language is a part of a culture and a culture is a part of a language" and that "the acquisition of a second language $[\ldots]$ is also the acquisition of a second culture." The need to tackle cultural aspects has resulted in the FL teaching concept of intercultural communicative competence, which is considered part (and/or an extension) of every student's communicative competence (Byram 1997). Importantly, understanding the culture of the target language also contributes to students' awareness of "the distinctness of their own" (Skela 2014, 115).

Despite the multifarious and sometimes lacking definitions of terms such as "culture" and "intercultural communication" (see Limon 2007, 91-93 for some examples), it should be acknowledged that linguistic knowledge, which has been traditionally regarded as central in the language classroom, should be complemented by intercultural communicative skills. Or, as Liddicoat and Scarino $(2013,15)$ claim, "[i]f language is viewed as a social practice of meaningmaking and interpretation, then it is not enough for language learners just to know grammar and vocabulary." Liddicoat and Scarino propose that language should be understood as social practice supported by a communication system based on linguistic structures. Each of these layers "affords opportunities for intercultural learning" $(2013,17)$ that can be supported by the study of cultures.

The interweaving of language, thought and culture can be observed on various levels, such as the levels of vocabulary, pragmatics, social roles and socio-economic status. This article addresses mostly the lexical component by presenting not only the most frequent adjectives describing Americans, as reported by Slovenian students of English, but also some of the connotative meanings that the students assign to these words.

\subsection{Approaches to Culture in FL Teaching and Learning}

As Kramsch (2001, 5; also see Kramsch 2000; 1995a) puts it, "teaching English as culture and voice entails showing [the students] how the choices made by individual users of English, be they native or non-native, construct relationships among utterances, and between utterances and their recipients." Even though teachers usually agree that culture should be approached by developing students' "critical language awareness, interpretive skills, and historical consciousness" (Byram and Kramsch 2008, 21), this is not an easy task to accomplish.

A very common approach to integrating cultural content in the FL classroom is to equate cultures with nations, which includes a strong focus on national attributes and thus results in distinguishing between, for instance, American, Australian, British and Canadian cultures. Students taking such courses are expected to learn about what is (stereo)typical for these nations/cultures, about their 
geography, history, politics, economy, and the like. Liddicoat and Scarino explain $(2013$, 19) that, "[i]n such a view, [...] language is used primarily for naming events, institutions, people, and places." Unsurprisingly, in its exaggerated form, equating cultures with nations can become a breeding ground for stereotypes since such discourse is prone to exclude the outliers, that is, anything that departs from what is stereotypical for the observed culture. Equating cultures with nations thus "constrains what is considered as a cultural group and what is considered as the culture of any particular group" (Liddicoat and Scarino 2013, 18). A similar approach to cultural content in FL teaching includes a focus on norms and values, which, again, treats culture as something static and "leaves the learner primarily within his/her own cultural paradigm" (Liddicoat and Scarino 2013, 19-20).

Unfortunately, the teaching materials available for language/culture courses often propagate such teaching, by, as Limon $(2007,93)$ succinctly establishes, including content that is "superficial and clichéd" and relies "on easily assimilated national stereotypes and images that are easy to market." Hence, Liddicoat and Scarino $(2013,22)$ emphasise the importance of regarding culture as more than a (consistent) body of information but rather as a variable framework, which, according to Norton (as quoted in Liddicoat and Scarino 2013, 22), can be shaped by "time, place, and social category," as well as "age, gender, religion, ethnicity, and sexuality." In this respect, an FL teacher has to assume the complex role of a mediator providing factual knowledge, identifying some potentially erroneous preconceptions, and restructuring perceptions about our fluid realities.

\subsection{Culture and the Curriculum}

The role of culture in FL teaching and learning is also reflected in contemporary FL curricula. It has become standard for such documents to incorporate culture as part of interdisciplinary content. The practice is also encouraged by the Common European Framework of Reference for Languages (Council of Europe 2001; henceforth, CEFR), which, despite being a descriptive framework, has a significant impact on contemporary language policies. In Slovenia, this can be observed both on the primary and on the secondary level of FL instruction: the primary school curriculum (for students aged 6-14) explicitly targets the CEFR level A2, while the curriculum for general secondary schools (for students aged 15-18) targets the level B2. The documents contain numerous references to cultural aspects of language teaching. Not surprisingly, the cultural component is also present in the university-level curriculum for the study programme BA in English at the University of Ljubljana.

A closer examination of Slovenian curricular documents reveals that the curriculum for English in primary education (Eržen et al. 2011) consistently refers to intercultural communicative competence. It emphasizes knowledge about characteristics of various English-speaking cultures, awareness and respect of the differences in value systems, awareness of cultural variety, learning about social and cultural norms, habits and rules, developing intercultural sensitivity, comparing and analysing intercultural similarities and differences, and transcending stereotypes. In addition, the content related to the cultures studied is to encompass topics on geography, history, and culture.

Similarly, even the introductory definition of English as a school subject in the secondary school curriculum (Eržen et al. 2008) goes beyond the purely linguistic content: mentioned are the role of English in the globalized world and the significant role that the increasing amount of contact between world cultures plays in the teaching of English. The general aims of the document also state that through learning English students develop the competence for intercultural and interlinguistic 
communication. The presentation of other competences in the curriculum also routinely includes references to cultural elements - for instance, the document states that reading authentic literary texts in English develops students' general intercultural competence. ${ }^{1}$ Moreover, intercultural competence requires from students that they understand how to behave in various social circumstances, how to avoid stereotypes and prejudices, and how to respect the integrity of others. ${ }^{2}$ Secondary school students should also notice and recognize the relationships between different cultures, apply and interpret this knowledge, and develop cultural competences and knowledge in the realm of all four skills. The secondary school curriculum specifically mentions cultural content in the section on thematic areas: students should be familiar with the most important cultural achievements and popular culture; they should know the basic characteristics of various cultures; and they should be aware of cultural differences between, say, Slovenia and the US.

A comparable inclusion of cultural content can be observed in the BA-level university study programme in English at the University of Ljubljana. The programme offers cultural modules that consist of literature courses combined with the corresponding subjects on American, Australian, British or Canadian Society and Culture. According to the course descriptions, the emphasis is on studying culture, and developing cultural and intercultural awareness, understanding, and tolerance. The course content covers traditional high culture, geography, history, society, and popular culture, including sport. ${ }^{3}$

To summarize, the curricular documents described above share an explicit inclusion of the intercultural component in FL teaching/learning. Also detected can be an emphasis on national attributes, which is particularly relevant to our survey of stereotypes.

\subsection{Stereotypes}

Psychology provides several definitions of stereotypes. Schneider (2004, 17) claims that "there is no real consensus on what stereotypes are," his generalized definition being that they are "categorybased beliefs we have about people" (2004, 29). A more detailed definition by Hilton and Von Hippel (1996, 240), which is adopted for the purposes of this paper, presents them as "beliefs about the characteristics, attributes, and behaviours of members of certain groups." Furthermore, in line with Khan, Benda, and Stagnaro $(2012,3)$, stereotypes represent "a type of mental shortcut" that allows us to form quick and effortless judgments about the abundance of information competing for our attention at any given time - they can be useful, but also inaccurate and even leading to discriminatory behaviour.

In a seminal study on stereotypes about ethnic or nationality groups by Katz and Braly (1933), Princeton students - at that time mostly affluent, white Americans - were asked to examine a list of adjectives and select as many as they felt necessary to describe different social groups. They were also required to choose five adjectives that they felt were most representative of the groups. In addition, they could provide some words of their own to describe the groups. The results of the study revealed that stereotypes about ethnic groups are surprisingly consensual, especially with regard to negative traits. For instance, African Americans were commonly described negatively, as

For more on intercultural communicative competence with regard to FL literature learning in the Slovenian context, see Skela (2014).

2 This aim is challenging - it can be a paradox for FL teachers/learners to avoid stereotypes and teach/learn characteristic behaviour at the same time.

3 The Department of English and American Studies at the University of Maribor, Slovenia's second biggest university, pursues similar goals (for more, see http://www.ff.um.si/oddelki/anglistika-in-amerikanistika/?language id=1). 
superstitious and lazy, while white Americans were mostly attributed positive traits, such as being industrious or ambitious. These responses prompted Katz and Braly to describe racial prejudices as a highly consistent set of generalized stereotypes. Also, the findings suggested that stereotypes are products of culture, since the students had little or no personal experience with the groups they were making generalizations about.

The Katz and Braly study was repeated in the 1950s and in the late 1960s (Gilbert 1951; Karlins, Coffman, and Walters 1969) to explore the changes in the attitudes of Americans towards different social groups. Interestingly, the respondents in the second and third studies expressed concerns and uneasiness about the questions; this was interpreted as evidence of a change in the attitudes towards making generalizations. Moreover, even though there was still a high degree of consensus among the respondents on most of the traits associated with various social groups, the researchers noticed a shift towards adjectives with positive connotations. As one of the aims of this paper is to analyse and identify stereotypes about Americans, table 1 summarizes the most frequent traits assigned to them in the three Princeton studies.

TABLE 1. The most frequent attributes assigned to Americans in the Princeton studies.

\begin{tabular}{|l|l|l|}
\hline Katz and Braly (1933) & Gilbert (1951) & Karlins, Coffman, and Walters (1969) \\
\hline industrious & materialistic & materialistic \\
\hline intelligent & intelligent & ambitious \\
\hline materialistic & industrious & pleasure-loving \\
\hline ambitious & pleasure-loving & industrious \\
\hline progressive & individualistic & conventional \\
\hline
\end{tabular}

Some perceptions of American traits have been explored in Slovenia as well, namely, in a study conducted by Šabec (2000). While her questionnaire mainly scrutinized the attitudes of Slovenian students towards British English and American English, one of the tasks also required the respondents to attribute fifteen personal traits to either speakers of General British or speakers of General American. The speakers of American English were attributed adjectives that carry mostly positive connotations. The five most frequent adjectives listed were: 'relaxed', 'friendly', 'sociable', 'self-confident', and 'fluent' (for a complete list see Šabec 2000, 77).

The beliefs and mental shortcuts encompassed in stereotypes have not been overlooked in the realm of FL teaching. Byram and Kramsch (2008, 31-32) distinguish between linguistic/cognitive stereotypes (for instance, the concept of 'hard work' in the American culture), categorization/ evaluation stereotypes (Germans are 'orderly'), and the group myth stereotype, which involves "representations of collective national memory" (the authors give the concept of 'Oktoberfest' as an example). The present study explores the second type, that is, categorization/evaluation stereotypes, which Byram and Kramsch mark as the most problematic of the three types.

Byram and Kramsch (2008) propose that negative evaluations and categorizations can be avoided if students are offered "contact with a variety of people and points of view." This opinion is shared by Khan, Benda, and Stagnaro (2012, 6-7), who provide a useful overview of some well-established "theories and interventions" that should be used to deal with the potentially unfair inaccurate judgements about the world around us. Some of the approaches that they suggest to use in order to diminish or prevent the likely negative impact that stereotypes can have on the members of the 
group being stereotyped include: (1) personal contact (forming relationships with members of the group in question); (2) recategorization (expanding the groups by including in them members not previously included); (3) bookkeeping (listing confirming and disconfirming information about a stereotype based on the encounters with the target person); and (4) situational attribution training (avoiding the tendency to utilize negative behaviour to confirm the stereotype). Most of the above are applicable in a classroom setting.

\section{The Study}

\subsection{Participants}

Sixty-nine respondents participated in the study, which took place in 2013. Their ages ranged from 20 to 40, the average being $21.9\left(\sigma=2.7, \mu_{1 / 2}=21\right)$. Seventy-five percent of the participants were female (this is representative of the gender structure at the department where they study). All respondents were students of English at the University of Ljubljana with a very similar background in FL instruction: in order to enrol in the English Department they had to pass the Matura, the Slovenian secondary school-leaving examination in English, which is aligned with the CEFR as a B2-level examination. ${ }^{4}$ In line with the focus of the study, only the responses of the students who identified as Slovenian were analysed (the results from 8 respondents were excluded from the study on the basis of this criterion - they include short-term exchange students or other students from abroad who had by then not lived in Slovenia for an extended period of time).

\subsection{Instruments and Procedure}

The respondents were presented with a questionnaire consisting of two parts.

In Part 1 they were asked to list three traits that they thought were typical of Americans. This open question was followed by a question on the factors influencing their answers. Here the respondents were given three options (the closed-ended options "Personal experience" and "The media," and the open-ended option "Other"); they were allowed to choose or provide as many answers as they felt necessary.

In Part 2 of the questionnaire, the respondents were provided a list of words describing personality traits based on the Princeton trilogy (Katz and Braly 1993; Gilbert 1951; Karlins, Coffman, and Walters 1969) and the study by Devine and Elliot (1995). First, the students were asked to use the list of attributes to identify as many specific characteristics or traits as they thought were typical of Americans. Then they were asked to choose five of the traits that they thought were most typical of Americans. Finally, they were required to judge whether they see the five most typical attributes as positive, neutral, or negative.

Since the respondents were FL students and the list of traits was in English, they were allowed to look up any unknown words in a dictionary.

\subsection{Research Questions}

RQ1: What factors do the respondents consider the ones most significantly influencing their respondents' perceptions of Americans?

See Bitenc Peharc and Tratnik (2014) for overall CEFR alignment results, Ilc, Rot Gabrovec, and Stopar (2014) for a critical evaluation of the alignment project, and Ilc and Stopar (2014) for partial external validation. 
RQ2: What adjectives do the respondents list as describing stereotypically American traits?

RQ3: Which traits (unlimited selection) from the list of adjectives used in the studies on racial stereotypes do the respondents perceive as typically American?

RQ4: Which five traits from the list of adjectives in the studies on racial stereotypes do the respondents perceive as most representative of Americans?

RQ5: What are the attitudes (positive, neutral, negative) of the respondents towards the traits that they perceive as most typically American?

\subsection{Results}

With regard to the factors influencing perceptions about Americans (RQ1), the majority of the respondents $(85.5 \%)$ stated that their perceptions stem from the media. More than a third (34.8\%) also claimed that the perceptions of stereotypical Americans are based on personal experience. One respondent $(1.5 \%)$ added a comment of their own in this section of the questionnaire, saying that they do not believe in stereotypes.

In the open-ended section of the questionnaire on the adjectives the respondents would use to describe a typical American (RQ2), they listed 88 different traits. Since some were synonyms (for instance, 'stupid' and 'not bright'), the traits were finally grouped into 70 categories. The five most frequently mentioned traits are presented in table 2 .

TABle 2. Adjectives describing stereotypical Americans (open-ended question), N=69.

\begin{tabular}{|l|l|l|}
\hline Adjective(s) & No. of Answers & \% of Answers \\
\hline stupid, not bright, not smart, ignorant & 29 & 42.0 \\
\hline open-minded & 15 & 21.7 \\
\hline proud & 15 & 21.7 \\
\hline fat, obese, overweight & 14 & 20.3 \\
\hline egocentric, egotistic, self-absorbed & 8 & 11.6 \\
\hline
\end{tabular}

When the respondents were asked to consider a list of adjectives and select those that are typical of Americans (RQ3), their choices ranged from 9 to 70 adjectives (per respondent). Hence, on average each participant selected 27 adjectives $\left(\sigma=11.2, \mu_{1 / 2}=25\right)$. Table 3 presents the five most frequently chosen stereotyping adjectives.

TABLE 3. Adjectives selected as representing typical American traits (adjective checklist procedure), $\mathrm{N}=69$.

\begin{tabular}{|l|l|l|}
\hline Adjective(s) & No. of Answers & \% of Answers \\
\hline materialistic & 58 & 84.1 \\
\hline ambitious & 52 & 75.4 \\
\hline competitive & 52 & 75.4 \\
\hline patriotic & 52 & 75.4 \\
\hline talkative & 48 & 69.6 \\
\hline
\end{tabular}


The respondents were also asked to use the adjectives from the same checklist and to single out the five traits they feel are most typical of Americans (RQ4). Included on their lists were 71 different adjectives. The five most frequently chosen attributes are listed in table 4 .

TABLE 4. Adjectives chosen as the most representative of Americans (i.e., top five from the adjective checklist), $\mathrm{N}=69$.

\begin{tabular}{|l|l|l|}
\hline Adjective(s) & No. of Answers & \% of Answers \\
\hline patriotic & 32 & 46.4 \\
\hline materialistic & 26 & 37.7 \\
\hline ambitious & 20 & 29.0 \\
\hline competitive & 16 & 23.2 \\
\hline ignorant & 16 & 23.2 \\
\hline
\end{tabular}

Since the same adjective can be understood in different ways, the respondents also judged whether the five traits that they perceive as most typically American were positive, neutral, or negative (RQ5). Table 5 below shows the connotations they ascribed to the five most frequently selected traits.

TABLE 5. The attitudes of the respondents towards the five most frequently selected traits, $\mathrm{N}=69$.

\begin{tabular}{|l|l|l|l|}
\hline Adjective(s) & \% Positive & \% Neutral & \% Negative \\
\hline patriotic & 15.6 & 68.8 & 15.6 \\
\hline materialistic & 0 & 11.5 & 88.5 \\
\hline ambitious & 70.0 & 30.0 & 0 \\
\hline competitive & 43.8 & 25.0 & 31.3 \\
\hline ignorant & 0 & 0 & 100 \\
\hline
\end{tabular}

It should be noted, however, that among the 71 adjectives that appeared on the respondents' lists of five most stereotypical American traits, nearly a half (44.1\%) were judged as negative, a quarter $(24.9 \%)$ as neutral, and less than a third $(31.0 \%)$ as positive.

\section{Discussion}

The respondents' perceptions about adjectives describing stereotypical Americans are largely based on the information available in the media. While the true nature of media influence is still a contentious issue (for instance, see Browne and Hamilton-Giachritsis 2005), these responses are consistent with the finding that cultural and historical realities can be a common basis for stereotyped generalizations, which was also suggested in Gilbert's (1951) study on stereotypes. To continue, a third of the respondents specified personal experience as the basis for their answers, which attests to the extent of direct exposure FL students in Slovenia have to Americans, whether this means travelling to the US or encountering Americans in Europe. Both findings are relevant for the FL classroom context - the former as a reminder of the importance of media education, and the latter as a strong signal to the language teacher that the average Slovenian student nowadays very likely possesses pre-existing, first-hand knowledge of content related to the course (which should be exploited in the classroom). Also noteworthy is that one respondent expressed their 
discomfort with the topic of the questionnaire and thus partly corroborated one of the reported findings of the second and the third studies in the Princeton trilogy: since the mid-20th century, college students in America have been more reluctant to make generalizations about national or racial attributes.

The results of the survey also indicate the impact of using different methodologies (question types) in stereotype research (see Devine and Elliot 1995). The open question about the stereotypically American traits yielded an extensive list of 88 adjectives (though some were synonymous). The number of students who listed a specific trait - even one of the five most frequent ones - was consistently low (see table 2 in the section Results): the range of frequencies was between 11.6 and $42.0 \%$. The frequencies were significantly higher when the respondents were asked to select adjectives from the pre-set list using the adjectives checklist procedure: as table 3 shows, the most commonly chosen traits were chosen by $69.6 \%$ to $84.1 \%$ of the respondents. On the other hand, the question that required the respondents to list only five adjectives from the list resulted in the range of frequencies similar to that in the open ended-question, namely, in-between 23.2 and $46.4 \%$ (see table 4). We can also conclude that different question types yielded different results with regard to content: the most frequent attributes provided as answers to the open-ended question diverge significantly from the answers based on the checklist. In the classroom discussions following the survey, the respondents reported that their answers to the open-ended question were knee-jerk reactions (their most readily available associations about American character traits), whereas the list of attributes led them to a more careful consideration of typical American traits.

The majority of the adjectives in table 2 attest to the traditionally negative attitudes that Slovenians have towards the US. The 2013 study by the Meridian International Center and Gallup on US global leadership, ${ }^{5}$ for instance, places Slovenia among the countries with the highest disapproval rating of US leadership. Ranked as seventh on the list (with a disapproval rating of 57\%), Slovenia is in the company of Palestinian territories (80\%), Pakistan (73\%), Lebanon (71\%), Yemen (69\%), Iraq (67\%), and Egypt (57\%), see Hess, Calio, and Frohlich (2014) for more. Hess, Calio, and Frohlich also suggest that the negative attitudes towards the US seem to correlate with the citizens' negative opinion of their countries' government. Disregarding the wider historical context (especially that of the post-WWII period), their explanation can be substantiated in the Slovenian context by considering the unstable political climate of the recent years. Since 2012, Slovenia has undergone the formation of three governments led by prime ministers from three different political parties, and the political turmoil accompanying these changes included a number of public protests. The same reasons can explain the contrast between our findings and the findings of the study by Šabec (2000). ${ }^{6}$ We should emphasize, however, that the attitudes towards Americans presented here are not unilaterally negative - the data in table 5 show that only two out of the five most frequently chosen adjectives describing Americans were judged as completely or predominantly negative, namely, 'ignorant' and 'materialistic'.

Also worth noting is that only one of the top five adjectives selected by Slovenian students (table 4) matches the observations of American students in all three Princeton studies; that is, the trait 'materialistic'. The adjective is interpreted as mostly negative by Slovenians, which matches the negative connotations for the word in American English (i.e. being preoccupied with possessions as opposed to intellectual or spiritual things). Another attribute that both Slovenian and American

More on the study by Meridian International Center and Gallup is available here: http:/www.gallup.com/poll/168425/globalimage-leadership-rebounds.aspx.

6 Another factor explaining the different results in the study by Šabec (2000) may be her predominant focus on the varieties of English rather than on American personal traits. 
students assign to Americans is 'ambitious' - the adjective appeared in two of the Princeton studies and is also high on the list in the present study. Not all Slovenians regard 'ambitious' as having entirely positive connotations, which is hardly surprising for a post-socialist society. Incidentally, one of the examples of the typical uses for ambiciozen (ambitious) that can still be found in the latest edition of the Dictionary of Standard Slovenian (Gliha Komac et al. 2014, 82) is bolestno ambiciozen (morbidly ambitious). In contrast to 'materialistic' and 'ambitious', the adjectives 'patriotic', 'competitive' and 'ignorant' are exclusive to Slovenian perceptions of the most prominent American traits. The antonyms 'intelligent' (Americans about themselves) and 'ignorant' (Slovenians about Americans) further testify to this difference in (self-)perception. Hence, the results of the survey support the accepted view that the judgements that members of one culture have about themselves differ substantially from the judgements others have about them (see, for instance, Schneider's $(2004,527)$ elaboration of ingroup and outgroup effects).

The traits identified in the survey should prove a useful and practical resource for (Slovenian) FL teachers tackling US culture in their language classrooms. The most frequently selected adjectives represent a viable starting point for culture-based classroom activities. The general descriptions of the required intercultural competence levels that are provided in the curricular documents (see 2.3) can be easily translated into concrete topics and addressed explicitly in order to expand cultural knowledge and challenge some the often-inaccurate perceptions of the culture studied. Activities such as finding arguments to support or refute these perceptions; debating such perceptions with representatives of the target cultures; and examining in more detail the typical members of the stereotyped group (see Khan, Benda, and Stagnaro 2012; Byram and Kramsch 2008) may all revolve around the traits identified by the respondents in the survey.

As an example, let us consider some aspects of the most frequently chosen attribute in the openended question - the trait 'stupid'/'ignorant'. We can agree that Americans are often portrayed as lacking knowledge about the world outside the United States, and the global English media are no strangers to debates on such topics as the deficiencies of American educational system, the neverending battles on teaching evolution in schools, or the infamous lack of geographical knowledge a stereotypical American is likely to exhibit. The proverbial kernel of truth in this stereotype may be identified in the key findings of the PISA study (Program for International Student Assessment; see OECD 2014b), where US students typically perform rather poorly in mathematics and science (in 2012 the mean scores were 481 and 497, respectively), and are only average in reading (498 in 2012). ${ }^{7}$ On the other hand, the stereotype is relatively easily refuted by, for instance, examining the statistics that place the US among the top three performers in the field of research and development. Furthermore, we should note that, traditionally, elite US universities are ranked among the best in the world, and that there obviously exist sufficient pull factors to draw some of the most intelligent individuals to migrate to the US in the hope of realizing their American Dream. What is more, Slovenian students may also find it relevant that their PISA results are not noticeably better when compared to the US: Slovenia performed above average in mathematics and science (mean scores of 501 and 514 in 2012), but below average in reading (481). In fact, in 2002, Reindl described the similar results of the previous PISA study as "a rude awakening," especially since Slovenians perceive "the notion of a universally high literacy rate [...] a significant, almost mythic, element of the Slovenian national self-image."

The numbers represent the average student score per country. The average score among all OECD countries is 500 points with the standard deviation of 100 points; about two-thirds of test-takers in these countries achieve a score between 400 and 600 points (see OECD 2014a). 


\section{Conclusion}

The article presents a study on the stereotypes about Americans among Slovenian university students of English as a foreign language. The findings show (1) that Slovenian perceptions of Americans often differ from the judgements that Americans have about themselves (cf. the Princeton trilogy studies); (2) that these perceptions may not be stable (cf. Šabec 2000); and (3) that the adjectives Slovenians attribute to Americans range from positive to negative in their connotations. To substantiate these claims further, additional research is needed - for instance, the study should be extended to a more general sample of the Slovenian population; it should address in more detail the methodological issues described in the previous sections; and, ideally, it should be conducted longitudinally.

It is believed that the findings presented herein are readily applicable in an FL teaching context. The language classroom may remain predominantly language-centred; nevertheless, as language learners make their headway to higher proficiency, they should also become increasingly skilled in and aware of the competences that go beyond the narrowly linguistic ones. It is vital that their teachers aid them in their acquisition of these competences, guide them to reflect on their preconceptions about the target cultures, and consequently raise their intercultural awareness.

\section{References}

Bitenc Peharc, Suzana, and Alenka Tratnik. 2014. Umestitev nacionalnih izpitov iz angleščne v skupni evropski okvir. Zaključno poročilo o izvedbi projekta. Ljubljana: Državni izpitni center.

Brown, Douglas H. 2000. Principles of Language Learning and Teaching. 4th ed. White Plains: Pearson Education.

Browne, Kevin D., and Catherine Hamilton-Giachritsis. 2005. "The Influence of Violent Media on Children and Adolescents: A Public-Health Approach.” The Lancet 365 (9460): 702-10. doi:10.1016/S01406736(05)17952-5.

Byram, Katra, and Claire Kramsch. 2008. "Why Is It so Difficult to Teach Language as Culture?" The German Quarterly 81 (1): 20-34. doi:10.1111/j.1756-1183.2008.00005.x.

Byram, Michael. 1997. Teaching and Assessing Intercultural Communicative Competence. Clevedon: Multilingual Matters.

Byram, Michael, Bella Gribkova, and Hugh Starkey. 2002. Developing the Intercultural Dimension in Language Teaching: A Practical Introduction for Teachers. Strasbourg: Council of Europe.

Council of Europe. 2001. Common European Framework of Reference for Languages: Learning, Teaching, Assessment. Cambridge: Cambridge University Press.

Deutscher, Guy. 2011. Through the Language Glass: Why the World Looks Different in Other Languages. London: Arrow Books.

Devine, Patricia G., and Andrew J. Elliot. 1995. "Are Racial Stereotypes Really Fading? The Princeton Trilogy Revisited." Personality and Social Psychology Bulletin 21 (11): 1139-50. doi:10.1177/01461672952111002.

Eržen, Vineta, Alenka Budihna, Berta Kogoj, Blanka Klobučar, Boštjan Vrecl, Ingrid Zupanc-Brečko, Jelka Napast, Karmen Pižorn, Katica Semec Pevec. 2008. Učni načrt. Angleščina. Gimnazija: splošna, klasična, strokovna gimnazija: obvezni ali izbirni predmet in matura (420 ur). Ljubljana: Ministrstvo za šolstvo in šport, Zavod RS za šolstvo. Accessed June 22, 2014. http://portal.mss.edus.si/msswww/programi2012/ programi/media/pdf/un gimnazija/un anglescina gimn.pdf.

Eržen, Vineta, Berta Kogoj, Alenka Budihna, Blanka Klobučar, Ingrid Zupanc-Brečko, Boštjan Vrecl, Jelka Napast, Karmen Pižorn, Katica Semec Pevec, Melita Kukovec, and Alenka Paternoster. 2011. Učni načrt. 
Program osnovna šola. Angleščina. Ljubljana: Ministrstvo za šolstvo in šport, Zavod RS za šolstvo. Accessed June 22, 2014. http://www.mizs.gov.si/fileadmin/mizs.gov.si/pageuploads/podrocje/os/prenovljeni_UN/ UN anglescina.pdf.

Gilbert, Gustave Mark. 1951. "Stereotype Persistence and Change among College Students.” The Journal of Abnormal and Social Psychology 46 (2): 245-54. doi:10.1037/h0053696.

Gliha Komac, Nataša, Nataša Jakop, Boris Kern, Simona Klemenčič, Domen Krvina, Nina Ledinek, Mija Michelizza, Tanja Mirtič, Andrej Perdih, Špela Petric, and Marko Snoj. 2014. SSKJ 2*, Slovar slovenskega knjižnega jezika, druga, dopolnjena in deloma prenovljena izdaja. Izdala Slovenska akademija znanosti in umetnosti in Znanstvenoraziskovalni center Slovenske akademije znanosti in umetnosti Inštitut za slovenski jezik Frana Ramovša. Ljubljana: Cankarjeva založba.

Hess, Alexander E.M., Vince Calio, and Thomas C. Frohlich. 2014. "Nine Countries That Hate America Most.' 24/7 Wall St., April 10. Accessed August 22, 2014. http://247wallst.com/special-report/2014/04/10/ninecountries-that-hate-america-most/.

Hilton, James L., and William von Hippel. 1996. “Stereotypes.” Annual Review of Psychology 47 (1): 237-71. doi:10.1146/annurev.psych.47.1.237.

Ilc, Gašper, Veronika Rot Gabrovec, and Andrej Stopar. 2014. "Relating the Slovenian secondary school English language national examinations to the CEFR: findings and implications." Linguistica 54 (1): 293-308. doi:10.4312/linguistica.54.1.293-308.

Ilc, Gašper, and Andrej Stopar. 2014. "Validating the Slovenian National Alignment to CEFR: The Case of the B2 Reading Comprehension Examination in English." Language Testing (forthcoming): 1-20. doi: $10.1177 / 0265532214562098$.

Karlins, Marvin, Thomas L. Coffman, and Gary Walters. 1969. "On the Fading of Social Stereotypes: Studies in Three Generations of College Students.” Journal of Personality and Social Psychology 13:1-16. doi:10.1037/ h0027994.

Katz, Daniel, and Kenneth Braly. 1933. "Racial Stereotypes in One Hundred College Students." Journal of Abnormal and Social Psychology 28:280-90. doi:10.1037/h0074049.

Khan, Saera, Teena Benda, and Michael N. Stagnaro. 2012. "Stereotyping From the Perspective of Perceivers and Targets." Online Readings in Psychology and Culture 5. Accessed December 21, 2014. http://scholarworks. gvsu.edu/orpc/vol5/iss1/1.

Konishi, Toshi. 1993. "The Semantics of Grammatical Gender: A Cross-Cultural Study." Journal of Psycholinguistic Research 22 (5): 519-34. doi:10.1007/BF01068252.

Kramsch, Claire. 1993. Context and Culture in Language Teaching. Oxford: Oxford University Press.

—. 1995a. "Rhetorical Models of Understanding." In Functional Approaches to Written Texts: Classroom Applications, edited by Thomas Miller, 61-78. Paris: United States Information Agency.

—. 1995b. "The Cultural Component of Language Teaching." Language, Culture, and Curriculum 8 (2): 83-92. doi:10.1080/07908319509525192.

—. 2000. "Social Discursive Constructions on Self in L2 Learning." In Sociocultural Theory and Second Language Learning, edited by James P. Lantolf, 133-53. Oxford: Oxford University Press.

—. 2001. "Language, Culture, and Voice in the Teaching of English as a Foreign Language." NovELTy 8 (1): 4-21.

Liddicoat, Anthony J., and Angela Scarino. 2013. Intercultural Language Teaching and Learning. Chichester: Wiley-Blackwell.

Limon, David. 2007. "Culture and the Lingua Franca: New Shore or Fata Morgana?” In English Studies in Flux: New Peaks, New Shores, New Crossings, edited by Eva-Maria Graf and Allan James, 91-102. Tübingen: Narr Dr. Gunter. 
OECD. 2014a. "About PISA. PISA FAQ. Background and Basics.” Accessed April 23, 2015. http://www.oecd. org/pisa/aboutpisa/pisafaq.htm.

-. 2014b. PISA 2012 Results in Focus. What 15-Year-Olds Know and What They Can Do with What They Know. OECD, Programme for International Student Assessment. Accessed January 4, 2015. http://www.oecd.org/ pisa/keyfindings/pisa-2012-results-overview.pdf.

Plemenitaš, Katja. 2014. “Gender Ideologies in English and Slovene: A Contrastive View.” ELOPE 11 (1): 1729. doi: 10.4312/elope.11.1.17-29.

Reindl, Donald F. 2002. “Are most Slovenes 'Document (Il)Literate?” Radio Free Europe, Radio Liberty, Media Matters 2 (2), January 14. Accessed January 30, 2015. http://www.rferl.org/content/article/1343776.html.

Schneider, David J. 2004. The Psychology of Stereotyping. New York: Guilford Press.

Skela, Janez. 2014. “The Quest for Literature in EFL Textbooks - A Quest for Camelot?” ELOPE 11 (1): 11336. doi:10.4312/elope.11.1.113-136.

Šabec, Nada. 2000. "British English vs. American English in a University Setting." Vestnik 34 (1/2): 75-86.

Whorf, Edward. 1956. “The Relation of Habitual Thought and Behavior to Language.” In Language, Thought, and Reality: Selected Writings of Benjamin Lee Whorf, edited by John B. Carroll, 134-59. Cambridge: MIT Press. 